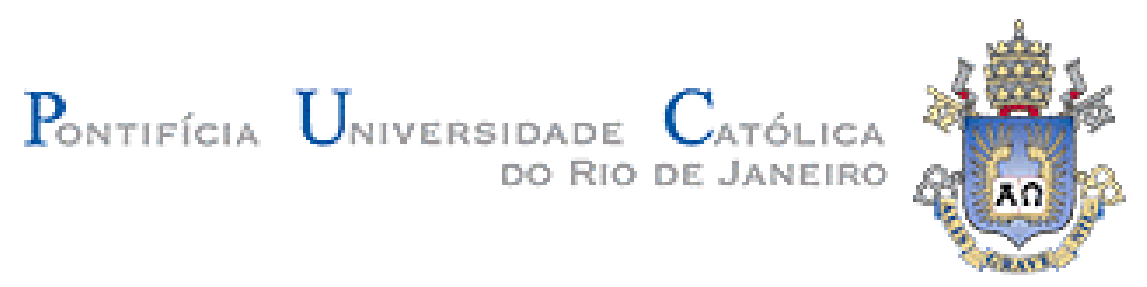

Till Felix Reichardt

\title{
Technical and Economic Assessment of Medium Sized Solar-Assisted Air-Conditioning in Brazil
}

\section{DISSERTAÇÃO DE MESTRADO}

Dissertation presented to the Postgraduate Program in Urban and Environmental Engineering of the Departamento de Engenharia Civil, PUC-Rio as partial fulfillment of the requirements for the degree of Mestre m Engenharia Urbana e Ambiental (opção Profissional).

Advisor: Prof. Celso Romanel

Co-Advisor: Profa. Elizabeth Duarte Pereira

Rio de Janeiro January 2010 


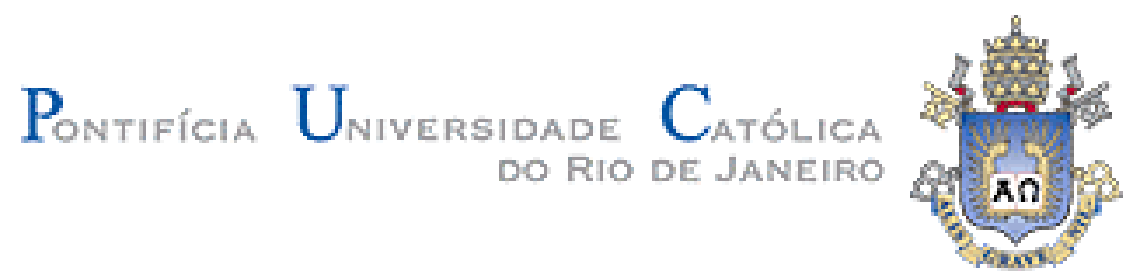

Till Felix Reichardt

\title{
Technical and Economic Assessment of Medium Sized Solar-Assisted Air-Conditioning in Brazil
}

\begin{abstract}
Dissertation presented to the postgraduate Program in Urban and Environmental Engineering of the Departamento de Engenharia Civil do Centro Técnico Científico da PUC-Rio, as partial fulfillment of the requirements for the degree of Mestre.
\end{abstract}

Prof. Celso Romanel

Orientador, PUC-Rio

Profa. Elizabeth Duarte Pereira Co-Orientadora, Grupo Anima de Educação

Dr. Johannes Kissel

GTZ-Brasil

Dr. Marcos Alexandre Teixeira

GTZ-Brasil

Prof. Alcir de Faro Orlando Departamento de Engenharia Mecânica, PUC-Rio

Prof. José Eugênio Leal Coordenador Setorial do Centro

Técnico Científico, PUC-Rio

Rio de Janeiro, 25/01/2010 
All rights reserved.

\section{Till Felix Reichardt}

Graduated in Environmental and Production Engineering from Technical University of Heilbronn, Germany, in 2006. Worked as a design engineer for the company Bartec Benke GmbH (Hamburg, Germany) during two years.

Bibliographic data

Reichardt, Till Felix

Technical and Economic Assessment of Medium Sized Solar-Assisted Air-Conditioning in Brazil / Till Felix Reichardt; advisor: Celso Romanel, co-advisor: Elizabeth Duarte Pereira; Rio de Janeiro: PUC, Departamento de Engenharia Civil, 2010.

135 f.: il. $29,7 \mathrm{~cm}$

Dissertação (Mestrado em Engenharia Urbana e Ambiental) - Pontifícia Universidade Católica do Rio de Janeiro, Rio de Janeiro, 2010.

Bibliographic references included.

1. Engenharia Urbana e Ambiental - Teses 2. Ar condicionado solar. 3. Coletores solares térmicos. 4. Simulação da carga térmica de resfriamento. 5. Eficiência energética. 6. Estimativa econômica I. Romanel, Celso. II. Pereira, Elizabeth Duarte. III Pontifícia Universidade Católica do Rio de Janeiro. Departamento de Engenharia Civil IV. Título. 
Ever bigger machines, entailing ever bigger concentrations of economic power and exerting ever greater violence against the environment, do not represent progress: they are a denial of wisdom. Wisdom demands a new orientation of science and technology towards the organic, the gentle, the nonviolent, the elegant and beautiful.

E. F. Schumacher Small Is Beautiful: a study of economics as if people mattered 


\section{Acknowledgments}

The author would like to thank Prof. Celso Romanel and Profa. Elizabeth Duarte Pereira for their guidance and support, anyone at DAAD (especially Karin Führ) for financial support during my master's degree program in Rio de Janeiro, Brazil

Special thank to the GTZ team in Rio de Janeiro, especially to Dr. Johannes Kissel, Dr. Marcos Teixeira and Andreas Nieters for their inspiration, discussion, support and information.

Very grateful I am also for the collaboration with PROCEL, especially with Andre Cleiman and Luciana Lopes Batista.

Katrin Spiegel (SolarNext), Ralf Kynast (Solvis), Bud Leavell (Yazaki), Christian Zahler (Mirroxx), Luiz Alexandre Alves (Cumulus), Alexandre Lopes (Benco) and Gabriel Neumeyer (Schüco) thanks for answering immediately a lot of essential technical questions.

Finally, I would like to thank Robert Mack (engineering consultant) for an excellent introduction in thermal building simulation and information about airconditioning and solar collectors.

Last but not least I would like to thank my family and Mariana Sales Fernandez Dominguez for their support. 


\section{Resumo}

Till Felix Reichardt, Romanel, Celso (Orientador); Pereira, E. (Coorientadora). Análise técnica e econômica de sistemas de arcondicionado de médio porte assistido por energia solar térmica no Brasil. Rio de Janeiro, 2010. 135 p. Dissertação de Mestrado Departamento de Engenharia Civil, Pontifícia Universidade Católica do Rio de Janeiro.

No Brasil, devido ao clima tropical, muita energia elétrica é utilizada em sistemas de ar condicionado. Devido à excelente irradiação solar que incide na maior parte do país, existem boas condições para atender esta grande demanda de refrigeração através da utilização de sistemas de ar condicionado assistido por energia solar térmica. Nesta dissertação, as mais importantes tecnologias que utilizam a energia solar para a climatização foram verificadas quanto a sua aplicabilidade técnica e econômica no Brasil, com foco em sistemas de médio porte. Os princípios básicos para o dimensionamento de um sistema de refrigeração solar são descritos e um estudo de caso é apresentado e discutido, comparando-se um sistema de ar condicionado assistido por energia solar (auditório em Guaratinguetá, São Paulo) com um sistema tipo split convencional. No estudo deste caso, a dinâmica de simulação térmica de edifícios foi modelada utilizando o programa Helios-PC. Também se analisa como a carga térmica de resfriamento pode ser diminuída considerando-se uma temperatura adequada no interior da edificação, de acordo com as normas brasileiras de conforto térmico, como também pelo emprego de isolamento adequado na construção do edifício.

\section{Palavras - chave}

Ar condicionado solar; Coletores solares térmicos; Simulação da carga térmica de resfriamento; Eficiência energética; Estimativa econômica. 


\section{Abstract}

Till Felix Reichardt, Romanel, Celso (Advisor), Pereira, Elizabeth Duarte (Co-advisor). Technical and economic assessment of medium sized SolarAssisted Air-Conditioning in Brazil. Rio de Janeiro, 2010. 135 p. M.Sc. Dissertation - Departamento de Engenharia Civil, Pontifícia Universidade Católica do Rio de Janeiro.

In Brazil a lot of electrical energy is used by building air-conditioning because of the tropical climate. In many cases there is a general congruence of solar irradiation and demand for building air-conditioning and solar thermal cooling has the potential to satisfy a part of the rapidly growing cooling demand. Due to excellent solar irradiance and a high cooling demand there exists in Brazil good conditions for the use of solar-assisted air-conditioning. In this work the most important solar cooling techniques and their suitability in Brazil are discussed. The objective of the present study is to analyze the technical and economic feasibility of medium sized solar-assisted air-conditioning in Brazil. The energy saving potential of solar-thermal air-conditioning in comparison to best practical solutions in Brazil using conventional split air-conditioning systems, is shown based on a case study (auditorium in Guaratinguetá - São Paulo). The economy of solar-assisted air-conditioning is thereby discussed. The basic principles for the dimensioning of a system for solar cooling are described. The auditorium in the case study is modelled by using the dynamic thermal building simulation program Helios-PC. In this context it is, as well, demonstrated how the cooling load could be decreased by adapting the indoor temperature according to the Brazilian standards of thermal comfort and by using building insulation.

\section{Keywords}

Solar cooling air-conditioning; Solar thermal collectors; Dynamic thermal building simulation; Energy efficiency; Economic assessment. 


\section{Zusammenfassung}

Till Felix Reichardt, Romanel, Celso (Betreuer); Pereira, Elizabeth Duarte (Zweitbetreuerin). Technical and economic assessment on medium sized Solar-Assisted Air-Conditioning in Brazil. Rio de Janeiro, 2010. 135 S. Abteilung Bauingenieurwesen, Departamento de Engenharia Civil, Pontifícia Universidade Católica do Rio de Janeiro.

In Brasilien wird aufgrund des tropischen Klimas, ein großer Anteil der elektrischen Energie für die Kühlung von Gebäuden verwendet. Aufgrund des stark wachsenden Klimakältebedarfs und der hervorragenden solaren Einstrahlbeding ergeben sich gute Bedingungen für den Einsatz von solarthermischer Klimakälteerzeugung. Hierbei stimmt das Angebot an solarer Einstrahlung zeitlich weitgehend mit dem Klimakältebedarf überein. In der vorliegenden Masterarbeit werden die wichtigsten Verfahren zur solaren Kälteerzeugung und ihre Eignung in Brasilien erörtert. Daraufhin wird anhand einer Fallstudie (Hörsaal in Guaratinguetá - São Paulo) überprüft, in wie weit solarthermische Klimakälteerzeugung eine energieeffiziente Alternative gegenüber Split-Kompaktklimageräten sein kann. Dabei wird anhand einer thermischen Gebäudesimulation zur Kühllastberechnung ermittelt, wie hoch der solare Deckungsgrad wäre. In diesem Kontext wird dargestellt, wie die Kühllast durch die Anpassung der Raumtemperatur an die brasilianischen Normen für thermischen Komfort und durch Gebäudeisolierung gesenkt werden könnte. Abschließend wird die Wirtschaftlichkeit von solarthermischer Klimakälteerzeugung im in Brasilien überprüft. Das thermische Verhalten des Hörsaals ist durch das dynamische Gebäudesimulationsprogramm Helios-PC abgebildet.

\section{Schlüsselwörter}

Solares Kühlen; Klimaanlage; Solarkollektoren; Dynamische Gebäudesimulation; Kühllast; Energieeffizienz; Wirtschaftlichkeitsberechnung. 


\section{Contents}

$\begin{array}{ll}1 \text { Introduction } & 18\end{array}$

$\begin{array}{ll}\text { 1.1. Objective } & 25\end{array}$

2 Technical overview of active techniques 26

2.1. Technologies applicable for solar-assisted air-conditioning 26

2.1.1. Chilled water systems 33

2.1.1.1. Absorption Chillers 34

2.1.1.2. Adsorption Chillers $\quad 40$

2.1.1.3. Heat Rejection 44

2.1.2. Open cycle Processes 46

2.1.3. Solar thermal collector 50

2.2. Non- thermally driven application 55

2.2.1. Conventional Electricity driven vapour compression chiller 55

2.2.2. Photovoltaic driven compression cycle 57

3 Case Study $\quad 62$

3.1. Background Information 63

3.1.1. Location and climate conditions 65

3.2. Simulation and Design 68

3.2.1. The thermal Load of the Building 68

3.2.1.1. Simulation Building Data 69

3.2.1.2. Results of the Simulation 74

3.2.1.2.1. Conclusion 77

3.2.2. Selection and Design of the equipment 79

3.2.2.1. The Cold Production Sub-System 80

3.2.2.2. The load sub-system - air-conditioning equipment 83

3.2.2.3. Heat production sub-system 87

3.2.2.3.1. Thermal solar collector comparison 87

3.2.2.3.2. Back-up and hot water storage 91

3.2.2.3.2.1. Electrically driven compression chiller back-up 92 
3.2.2.3.2.2. Thermal gas driven back-up 93

3.2.2.4. Design and performance of the complete system 95

3.2.2.4.1. Conclusion 101

3.2.3. Economic assessment 104

3.2.3.1. Acquisition and operation cost calculation 104

3.2.3.2. Economic feasibility 107

3.2.4. Environmental benefits 109

3.2.5. Conclusion 110

4 Conclusion and recommendations 112

$\begin{array}{ll}\text { References } & 117\end{array}$

$\begin{array}{ll}\text { Appendix } & 120\end{array}$

A1 Specification for the Auditorium 120

A2 Technical Data and Information 128

A3 Solar collector Test certificates 130

A4 Quotations 134 


\section{List of figures}

Figure 1.1 - Okura Act City Hotel in Hamamatsu, Japan 19

Figure 1.2 - Megacities of the tropical Belt 20

Figure 1.3 - Applied electrically driven compression Air-Conditioning 21

Figure 1.4 - World market sales rate in 2008 of split air-conditioners 22

Figure 2.1 - General Scheme of the thermally driven cooling process 27

$\begin{array}{lr}\text { Figure } 2.2 \text { - Closed cycle system } & 28\end{array}$

$\begin{array}{ll}\text { Figure 2.3 - Open sorption cycle } & 29\end{array}$

Figure 2.4 - Thermodynamic principle of thermally driven cooling 29

Figure 2.5 - Theoretic limit of solar thermal driven cooling processes 31

Figure 2.6 - Example manufacturer Data 32

Figure 2.7 - Exemplary curves of the coefficient of performance COP 32

Figure 2.8 - Schematic drawing of an absorption chiller 34

Figure 2.9 - Vapour pressure as a function of vapour temperature 35

Figure 2.10 - Detail function scheme of a single-effect Absorption chiller 36

Figure 2.11 - Typical capacity range of a absorption chillers 37

Figure 2.12 - Global solar radiation map of Brazil 38

Figure 2.13 - Examples of concentration solar thermal collectors 39

Figure 2.14 - Two examples of absorption chiller 40

Figure 2.15 - Scheme of an adsorption chiller 41

Figure 2.16 - Two Examples of adsorption chillers 41

Figure 2.17 - Available adsorption chillers 43

Figure 2.18 - Example on the demand for heat rejection 44

Figure 2.19 - Typical scheme of an open wet cooling tower 45

Figure 2.20 - Scheme of a solar thermally driven solid DEC system 46

Figure 2.21 - Relative humidity of the air in relation to the max. Temp. 49

Figure 2.23 - Examples for different construction principles 51 
Figure 2.24 - Examples on solar collectors $\quad 54$

Figure 2.25 Schematic drawing of a vapour compression chiller 55

Figure 2.26 - Function scheme of a Split Air-conditioning system 56

Figure 2.27 - Solar cooling possibilities $\quad 58$

Figure 2.28 - Comparison of COP's and efficiency 59

Figure 2.29 - Surface and atmospheric temperatures 59

Figure 2.30 - Low/high albedo of a solar thermal collector and PV 61

Figure 3.1 - Interaction in the design and layout 63

Figure 3.2 - Location of Guaratinguetá in Brazil 65

Figure 3.3 - Global solar radiation map 66

$\begin{array}{ll}\text { Figure 3.4 - Brazilian south-eastern Megalopolis } & 67\end{array}$

Figure 3.5 - External/internal cooling loads (modified) 69

Figure 3.6 - Snapshot of HELEX 2.1 Interface $\quad 72$

Figure 3.7 - Predicted monthly cooling load 75

Figure 3.8 - Hourly cooling load pattern (hourly data) 76

Figure 3.9 - "With Springer you are the one who makes the climate" 77

Figure 3.10 - Insulation with EPS Polystyrene plates in Germany 78

Figure 3.11 - Sub-systems and their components (modified) 80

Figure 3.11 - Performance characteristics of Yazaki WFC-SC10 81

Figure 3.12 - Technical data wet cooling tower 83

Figure 3.13 - Generic classification of centralised air-conditioning 84

Figure 3.14 - Example of a Cooling panel 86

Figure 3.15 - Cross-section of a typical simple fan-coil unit 86

Figure 3.16 - Schematic illustration showing the inclination of the sun 88

Figure 3.17 - Definition of collectors areas $\quad 90$

Figure 3.18 - Predicted performance of different solar collectors 90

Figure 3.19 - Simplified scheme of a solar cooling system 92

Figure 3.20a - Simple comparison of CO2 emissions 93

Figure 3.20b - In comparison to Figure 3.20a 93

Figure 3.21 - Simplified scheme of a solar cooling system 94 
$\begin{array}{lr}\text { Figure } 3.22 \text { - Snapshot of generic spreadsheet } & 97\end{array}$

Figure 3.23 - Predicted correlation between cooling demand/yield 97

Figure 3.24 - Predicted correlation between cooling demand/yield 98

Figure 3.25 - Predicted correlation between cooling demand/yield 98

Figure 3.26 - Predicted daily demand and available yield (spring) 99

Figure 3.27 - Predicted daily demand and available yield (summer) 99

Figure 3.28 - Predicted daily demand and available yield (autumn) 100

Figure 3.29 - Predicted daily demand and available yield (winter) 100

Figure 3.30 - Predicted total monthly cooling demand and yield (Brazil) 101

Figure 3.31 - Predicted monthly demand and yield (UK) 102

Figure 3.31 - Schematic diagram of the simulated solar cooling syst. 103

Figure 3.32 - Example of an Solar-Assisted Air-conditioning application 103

Figure 3.33 - Acquisition and operation cost (Guaratinguetá) 108

Figure 3.34 - Acquisition and operation cost (Minas Gerais) 108

Figure 4.1 - Typical electric driven screw chiller power curve 115 


\section{List of tables}

Table 2.1 - Cooling Capacity of Absorption- and Adsorption chiller 42

Table 3.1 - Monthly average climate data of Guaratinguetá 66

Table 3.2 - U-values of the auditorium building model $\quad 71$

Table 3.3 - Internal thermal comfort (PNB-10, Brazil) 73

$\begin{array}{ll}\text { Table } 3.4 \text { - Cooling Load results without building insulation } & 74\end{array}$

Table 3.5 - Cooling Load results with building insulation 75

Table 3.6 - Technical data of the Yazaki WFC-SC10 Absorption Chiller 81

Table 3.7 - Cooling water temperatures $\quad 82$

Table 3.8 - Specific cooling capacities of different AC systems 84

Table 3.9 - Characteristic values and cost of solar collector typologies 89

$\begin{array}{ll}\text { Table } 3.10 \text { - Acquisition and specific costs } & 105\end{array}$

Table 3.11 - Comparison of electricity consumption and operation cost 106

$\begin{array}{lr}\text { Table } 3.12 \text { - CO2 savings per year } & 109\end{array}$ 


\section{List of symbols}

\begin{tabular}{ll}
$A$ & area \\
$a_{1}$ & heat transfer coefficient \\
$a_{2}$ & temperature depending heat transfer coefficient \\
$C O P_{\text {Sol }}$ & solar collector efficiency \\
$C_{w}$ & heat capacity of water \\
$G$ & solar irradiance at collector surface \\
$h_{\text {amb }}$ & enthalpy ambient air \\
$h_{\text {supply }}$ & enthalpy air supply \\
$m_{(t)}$ & water flow \\
$m_{\text {supply }}$ & mass air flow \\
$P_{\text {el }}$ & electric power input \\
$Q$ & cooling capacity \\
$Q_{\text {cold }}$ & useful cold \\
$Q_{\text {drive }}$ & driving heat \\
$Q_{\text {reg }}$ & external regeneration heat \\
$t_{a}$ & ambient temperature \\
$T_{C}$ & low temperature \\
$T_{H}$ & high temperature \\
$T i$ & indoor temperature \\
$t_{m}$ & average temperature solar collector \\
$T_{M}$ & medium temperature \\
$\Delta T$ & temperature difference \\
$\eta$ & efficiency factor \\
$\eta_{0}$ & optical efficiency solar collector \\
$\eta_{\text {coll }}$ & efficiency factor solar collector \\
& \\
\hline &
\end{tabular}




\section{List of acronyms and abbreviations}

HVAC

IR

Eletrobrás

PROCEL

UNESP

GTZ

ASHRAE

INMETRO

INMET

GREENSolar
Heating, Ventilating and Air Conditioning

Infrared Radiation

Brazilian energy company with headquarters in Rio de Janeiro. The company produces and sells electricity. The majority of the share capital is held by the Brazilian government. It is the biggest energy company in Brazil as well as in Latin America.

Brazilian Energy Saving Program

São Paulo State University

German Technical Cooperation. The GTZ GmbH is an international cooperation enterprise for sustainable development with worldwide operations.

American Society of Heating, Refrigerating and AirConditioning Engineers

Brazilian Institute of Metrology, Standardization and Industrial Quality

Brazilian Institute of Meteorology

Is the only Brazilian laboratory which is testing solar collectors for the INMETRO 
DEC

COP

EER
Desiccant Evaporative Cooling

Open cycle air-conditioning process.

Central components: sorptive air dehumidification, using either solid or liquid sorption material; heat recovery unit; return (and often supply) air humidifiers. Requires separate supply and return air ducts.

\section{Coefficient of Performance}

Performance number of thermally driven chillers:

Ratio of (cold production) / (driving heat input) Used with power units $(\mathrm{kW} / \mathrm{kW})$ to provide rated values, or with energy units $(\mathrm{kWh} / \mathrm{kWh})$ to provide the performance during longer periods.

\section{Electrical Efficiency Ratio}

Performance number of electrically driven compression chillers: Ratio of (cold production) / (electricity input). Used with power units $(\mathrm{kW} / \mathrm{kW})$ to provide rated values, or with energy units $(\mathrm{kWh} / \mathrm{kWh})$ to provide the performance during longer periods. 